\title{
CU-M90: A Black Dry Bean Breeding Line Resistant to Clover Yellow Vein Virus
}

\author{
B. Scully ${ }^{1}$ \\ Everglades Research and Education Center, Institute of Food and \\ Agricultural Sciences, University of Florida, Belle Glade, \\ FL 33430-8003

\section{R. Provvidenti ${ }^{2}$} \\ New York State Agricultural Experiment Station, Cornell University, \\ Geneva, NY 14456

\section{D.E. Halseth ${ }^{3}$} \\ Department of Vegetable Crops, Cornell University, Ithaca, NY 14853
}

\section{D.H. Wallace ${ }^{4}$ \\ Department of Plant Breeding and Biometry, Cornell University, Ithaca, NY 14853}

Additional index words. backcross method, bean common mosaic virus, cyv gene, Phaseolus vulgaris, vegetable breeding

Clover yellow vein virus (CYVV) is an aphid-transmitted viral agent capable of

Received for publication 14 May 1990. This research was supported by the Depts. of Vegetable Crops, Plant Breeding and Biometry, and Plant Pathology, Cornell Univ., and USAID Title XII Bean/Cowpea CRSP. We gratefully acknowledge the assistance of D. Benscher, J.G. Doss, W.L. Hymes, and Ligia Montorossa-Teñas. Plant Breeding and Biometry paper no. 789. The cost of publishing this paper was defrayed in part by the payment of page charges. Under postal regulations, this paper therefore must be hereby marked advertisement solely to indicate this fact.

'Assistant Professor (formerly: Graduate Research Assistant, Cornell Univ.).

${ }^{2}$ Liberty Hyde Bailey Professor of Plant Pathology.

${ }^{3}$ Assistant Professor.

${ }^{4}$ Professor. causing serious crop losses in common beans (Phaseolus vulgaris L.) throughout the Atlantic and Great Lakes regions of Canada and the United States. This virus was formerly known as the necrotic/severe strain of bean yellow mosaic virus (BYMV-N/BYMV-S) or as strain BYMV-III (Provvidenti and Schroeder, 1973; Tu, 1983). After infection, susceptible plants develop epinasty, stunting, pod distortion, leaf necrosis, and, occasionally, systemic vascular necrosis that can result in premature death. A high level of resistance to CYVV is conferred by the single recessive cyv gene (Provvidenti, 1987), formerly known as by-3 (Provvidenti and Schroeder, 1973), and found in 'Great Northern-1140'. This gene was later detected in 'Kentwood' (Tu, 1983) and differs from the two unnamed recessive genes found in 'Great Northern 31' that confer resistance to the necrotic strain of BYMV (Tatchell et al., 1985). The purpose of our breeding program was to incorporate the cyv allele into 'Midnight' (Sandsted, 1980). The name "CU-M90" denotes its origin at Cornell Univ. (CU), with 'Midnight' as the recurrent parent (M) and 1990 the year of release. This breeding line may be useful in Central and North American breeding programs, or wherever CYVV occurs.

\section{Origin}

The simultaneous backcross and self procedure (H.M. Munger, personal communication) was used to develop CU-M90. In a cross between 'Great Northern-1140' ('GN-1140') and 'Black Turtle Soup-1' (BT-1) (Provvidenti, 1983), a black-seeded $\mathrm{F}_{3}$ individual was identified with resistance

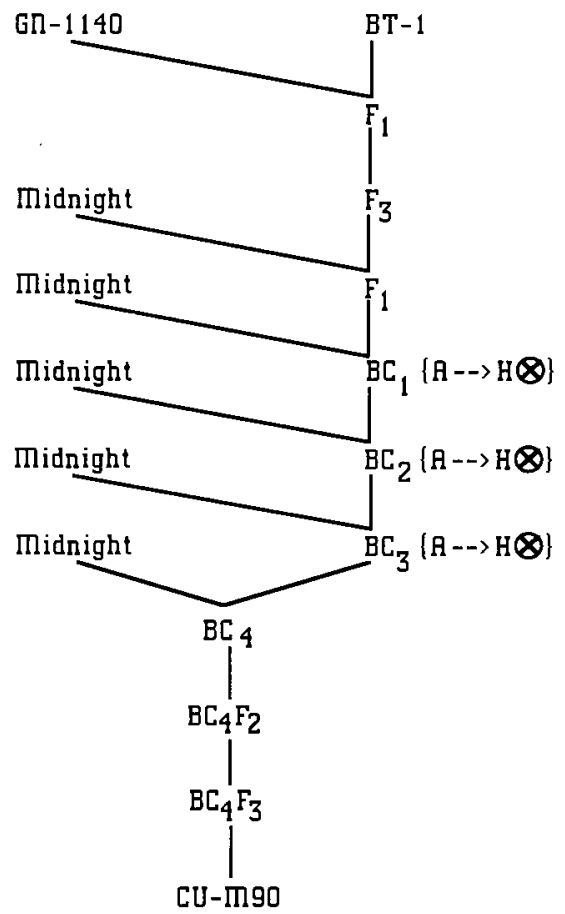

Fig. 1. Pedigree of CU-M90. 


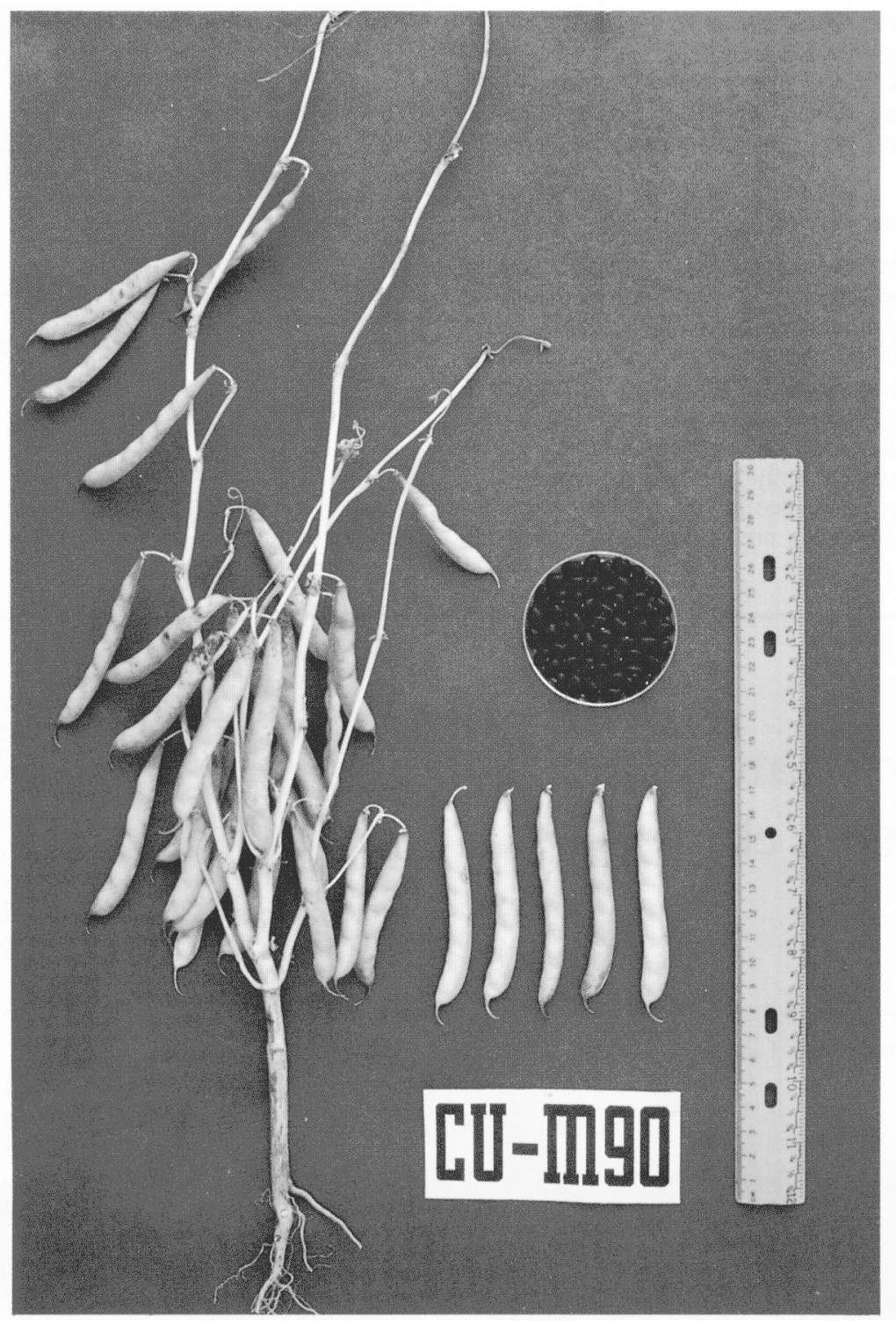

Fig. 2. Seeds, pods, and a dried plant of CU-M90.

to CYVV (Fig. 1). This plant was the male donor parent that carried the $c y v$ gene from 'GN-1140', while 'Midnight' was the recurrent female parent for five generations. In each backcross generation, eight plants (A to $\mathrm{H}$ ) were used as pollen parents and concurrently selfed to reveal the presence of the recessive $c y v$ gene. Twenty or more plants from each of the selfed pollen parents were mechanically inoculated at the primary leaf stage. Backcross progenies from crosses with the heterozygous pollen parents were carried forward to the next backcross generation; all other backcross progenies were discarded. The use of eight pollen parents provided better than a $99 \%$ chance of recovering at least one heterozygous male parent per backcross generation. In the $\mathrm{BC}_{4}-\mathrm{F}_{2}$ generation, one line was identified as CYVV-resistant. Twenty $\mathrm{F}_{3}$ progeny.

\section{Description}

slightly flattened, with five to seven seeds. As pods mature, a purple hue develops along the sutures, and dry pods become dark tan and purple. Pods are held relatively high on the plant, usually $\geq 10 \mathrm{~cm}$ above the soil. Pod apicule is purplish, curved, and \pm 1.0 $\mathrm{cm}$ long. Seed are dull black, and seed morphology is essentially the same as 'Midnight', with an average 100-seed weight of 22 to $25 \mathrm{~g}$. On average, CU-M90 flowers in 33 to 36 days after emergence and matures in 98 to 107 days, depending on location and year. First flowers form at the fourth node and open at about the fifth or sixth leaf stage.

As with 'Midnight', CU-M90 appears to carry some tolerance to damping off (Pythium ultimum Trow.) and root rot [Fusarium solani (Mort.) Appel and Wallenw. f. sp. phaseoli (Burk) Snyder and Hansen]. It is not resistant to white mold (Sclerotinia sclerotiorum (Lib.) de Bary) under field conditions, but may avoid serious infection because of its upright architecture. CU-M90 is resistant to strains U.S. 1 and NY 15 of bean common mosaic virus (BCMV), but susceptible to the NL-3, NL-5, and NL-8 pathotypes of BCMV and BYMV. CU-M90 is considered nearly isogenic with 'Midnight' and may be suitable for evaluation and release as a CYVV-resistant cultivar.

\section{Availability}

Small seed samples are available from D.H.W.

\section{Literature Cited}

Adams, M.W., D.P. Coyne, J.H.C. Davis, P.H. Graham, and C.A. Francis. 1985. Common bean (Phaseolus vulgaris L.), p. 433-476. In: R.J. Summerfield and E.H. Roberts (eds.). Grain legume crops. W. Collins Sons, London.

Provvidenti, R. 1983. Two useful selections of the bean cultivar 'Black Turtle Soup' for viral identification. Annu. Rpt. Bean Imp. Coop. 26:7375.

Provvidenti, R. 1987. List of genes in Phaseolus vulgaris for resistance to viruses. Annu. Rpt. Bean Imp. Coop. 30:1-4. homozygous resistance (cyv/cyv) confirmed. CU-M90 was derived from the bulked $\mathrm{BC}_{4}$ -

CU-M90 is an upright plant 40 to $60 \mathrm{~cm}$ high, with a height range similar to 'Midnight' (Fig. 2). Plants are stiff-stemmed and indeterminate (CIAT Type II) (Adams et al., 1985), with 12 to 16 mainstem nodes. Yield is carried on three or four prominent stems with short terminal runners $(4-8 \mathrm{~cm})$ that rarely intertwine. The flowers are purple, whereas stems, petioles, and stipules are lightly suffused with purple. Pods average 7 to $9 \mathrm{~cm}$ long and 9 to $11 \mathrm{~mm}$ wide and are
Provvidenti, R. and W.T. Schroeder. 1973. Resistance in Phaseolus vulgaris to the severe strain of bean yellow mosaic virus. Phytopathology 63:196-197.

Sandsted, R.F. 1980. Naming and release of 'Midnight' a new black bean cultivar. Dept. of Vegetable Crops Mimeogr. Ser. VC-239. Cornell Univ., Ithaca, N.Y.

Tatchell, S.P., J.R. Baggett, and R.O. Hampton. 1985. Relationship between resistance to severe and type strains of bean yellow mosaic virus. J. Amer. Soc. Hort. Sci. 110:96-99.

Tu, J.C. 1983. Inheritance in Phaseolus vulgaris cv 'Kentwood' of resistance to a necrotic strain of bean yellow mosaic virus and to a severe strain of tobacco ringspot virus. Can. J. Plant Pathol. 5:34-35. 